\title{
LUT
}

University

\section{End-of-life RO membranes recycling: Reuse as NF membranes by polyelectrolyte layer-by-layer deposition}

Moradi Mohammad Reza, Pihlajamäki Arto, Hesampour Mehrdad, Ahlgren Jonni, Mänttäri Mika

This is a Final draft version of a publication

published by Elsevier

in Journal of Membrane Science

DOI: $10.1016 /$ j.memsci.2019.04.060

Copyright of the original publication: (C) 2019 Elsevier B.V.

Please cite the publication as follows:

Moradi M.R., Pihlajamäki, A., Hesampour, M., Ahlgren, J., Mänttäri, M. (2019) End-of-life RO membranes recycling: Reuse as NF membranes by polyelectrolyte layer-by-layer deposition. Journal of Membrane Science, vol. 584, pp. 300-308. DOI: https://doi.org/10.1016/j. memsci.2019.04.060.

This is a parallel published version of an original publication. This version can differ from the original published article. 
End-of-life RO membranes recycling: reuse as NF membranes by polyelectrolyte layer-by-layer deposition

\author{
Mohammad Reza Moradi ${ }^{a}$, Arto Pihlajamäkia, ${ }^{a}$, Mehrdad Hesampour ${ }^{\text {a, b }}$, Jonni Ahlgren ${ }^{\mathrm{b}}$, Mika \\ Mänttäri ${ }^{\mathrm{a}}$ \\ ${ }^{a}$ LUT School of Engineering Science, Lappeenranta University of Technology, Lappeenranta 53851, \\ Finland \\ ${ }^{\mathrm{b}}$ Kemira Oyj, EMEA R\&D and Technology Center, Luoteisrinne 2, 02271, Espoo, Finland
}

\begin{abstract}
:
Nowadays, end-of-life (EoL) reverse osmosis (RO) membranes are considered as waste, hence they are incinerated or discarded in landfills. Due to the environmental problem of disposed membranes, their reuse as nanofiltration (NF) membranes was studied in this study. At first, the fouling of EoL membrane was cleaned and then the effect of sodium hypochlorite $(\mathrm{NaOCl})$ on removing the polyamide (PA) layer and pure water permeability (PWP) of EoL membranes was investigated. With regard to $\mathrm{NaOCl}$ exposure intensities, three groups of EoL membranes with PWP of about 10, 20, and $30 \mathrm{~L} /\left(\mathrm{m}^{2} \mathrm{~h}\right.$ bar $)$ were selected as substrates to convert them to NF membranes by deposition of polyelectrolyte (PE) multilayers. The effects of PE type, substrate permeability, and the charge of outer layer on the performance of the resultant NF membranes were studied. As one of the best results, NF membrane composed of eight bilayers of SC498/KE253 polyelectrolytes on substrates with PWP of $18 \mathrm{~L} /\left(\mathrm{m}^{2} \mathrm{~h}\right.$ bar) had salt water permeability (SWP) of $11 \mathrm{~L} /\left(\mathrm{m}^{2} \mathrm{~h}\right.$ bar) and $94 \%$ rejection of $\mathrm{MgSO}_{4}$. Other results are also competitive with commercial NF membranes. The maximum $\mathrm{NaCl}$ and $\mathrm{MgSO}_{4}$ rejection of prepared membranes were $92 \%$ and $98 \%$, respectively, at a feed pressure of 10 bar. In addition, the stability test showed that the prepared membranes are stable over a long period of filtration.
\end{abstract}

Keywords: EoL RO membrane, Recycling, Polyelectrolyte multilayers, NF membrane, Desalination.

\title{
1. Introduction
}

Reverse osmosis technology is one of the most commonly used methods for seawater desalination and wastewater purification. This is often done using thin film composite (TFC) membranes. Several factors affect TFC RO membranes lifetime ( $5-7$ years), one of which is the formation of fouling layer. The fouling is produced as a results of the removal of dissolved matter and particles in the feed, which can be classified as inorganic, organic and biological fouling [1].The disposal of TFC RO membranes after the end of their lifetime has negative effects on the environment, because most often EoL RO modules are incinerated to recover energy [2] or discharged in landfills. According to

\footnotetext{
${ }^{1}$ Corresponding author, arto.pihlajamaki@lut.fi, +358 401823867
} 
Landaburu-Aguirre et al. [3] and the latest data of the International Desalination Association (IDA) [4], the total mass of disposed modules was estimated to be more than 16,500 tons in 2018 , which indicates that the problem of disposed membranes needs urgent attention. This is in direct conflict with the objectives of the European Union in moving toward a circular economy system where the main purpose is to minimize waste.

Recycling EoL RO membranes is the most preferred option to achieve this purpose either as direct reuse or after conversion to ultrafiltration membranes [5]. This is because reusing has also economic interests and not just environmental benefits [6]. Direct reuse is divided into three categories: (1) rejuvenation of EoL membranes, (2) using for lower grade treatment and (3) using for new applications [5]. The rejuvenating treatment is done by cleaning agents in order to remove most of the fouling and scaling [7]. If the EoL membranes performance is not suitable after rejuvenating treatment, they can be used for lower grade treatment application like brackish water treatment and seawater pretreatment [8-12]. Apart from these, the EoL membranes can be employed in other application like utilizing in membrane biofilm reactor. Morón-López et al. used EoL RO membrane as the support for biofilm formation to selectively remove microcystins [13]. Chemical conversion is the chemical removal of ultrathin top layer and conversion of EoL membrane into microfiltration (MF) and ultrafiltration (UF) membranes [6, 14-18]. Rodriguez et al., as pioneering researchers in this area, converted EoL RO membranes to MF and UF membranes by removing the PA layer using strong chemical oxidants, like $\mathrm{NaOCl}$, hydrogen peroxide $\left(\mathrm{H}_{2} \mathrm{O}_{2}\right)$, and potassium permanganate $\left(\mathrm{KMnO}_{4}\right)[19,20]$. They concluded that $\mathrm{KMnO}_{4}$ with a dose of around $1000 \mathrm{ppm}$ was the most effective oxidative agent, which reduced salt rejection of RO membranes to $2 \%$.

Lawler et al. examined three solutions of sodium hydroxide $(\mathrm{NaOH}), \mathrm{KMnO}_{4}$, and $\mathrm{NaOCl}$ for removing the active layer of $\mathrm{RO}$ membranes [8]. After using $\mathrm{NaOCl}$ as the best oxidative agent, they found that the resulting UF membranes had better performance than commercial UF membranes in some cases.

Several similar pieces of research have been accomplished in recent years. Table 1 summarizes these. 
Table 1. Comparing the results of studies used $\mathrm{NaOCl}$ for removing PA layer of TFC RO membranes.

\begin{tabular}{lllll}
\hline Membrane type & $\begin{array}{l}\text { NaOCl exposure Intensity } \\
(\mathrm{ppm} h)[\mathrm{ppm} \times \mathrm{h}]\end{array}$ & $\begin{array}{l}\text { Water permeability } \\
\left(\mathrm{L} /\left(\mathrm{m}^{2} \mathrm{~h} \text { bar }\right)\right.\end{array}$ & $\begin{array}{l}\text { NaCl rejection } \\
(\%)\end{array}$ & Reference \\
\hline New BW30FR & $300000[6250 \times 48]$ & $175 \pm 4$ & $<4 \%$ & {$[8]$} \\
New BW30FR & $187500[62500 \times 3]$ & $175 \pm 4$ & $<4 \%$ & {$[8]$} \\
EoL BW (TM700) & 72000 & $\approx 40^{\mathrm{a}}$ & - & {$[8]$} \\
Lab-made & $131520[2740 \times 48]$ & 19.64 & 2.2 & {$[21]$} \\
New BW30FR & $300000[125000 \times 2.4]$ & $59 \pm 5$ & $<1 \%$ & {$[22]$} \\
EoL BW (CSM) & $300000[125000 \times 2.4]$ & $\approx 115$ & $<1 \%$ & {$[22]$} \\
EoL SW(TML820) & $300000[125000 \times 2.4]$ & $\approx 9$ & $<1 \%$ & {$[22]$} \\
EoL BW30 & $30000[124 \times 242]$ & $40.57 \pm 1.49$ & $1.68 \%$ & {$[18]$} \\
EoL BW (TM720) & $30000[124 \times 242]$ & $37.38 \pm 4.37$ & $1.51 \%$ & {$[18]$} \\
EoL SW30 & $30000[124 \times 242]$ & $33.80 \pm 1.68$ & $4.56 \%$ & {$[18]$} \\
EoL SW (TM820) & $30000[124 \times 242]$ & $11.03 \pm 1.41$ & $3.57 \%$ & {$[18]$} \\
EoL TW30 & $150000[10000 \times 15]$ & 18 & $<4 \%$ & {$[23]$} \\
EoL BW30 & $300000[55000 \times 5.4]$ & 116.7 & $12.6 \pm 0.2$ & {$[24]$} \\
\hline
\end{tabular}

a test with pure water

In this work, like the cited literature, $\mathrm{NaOCl}$ solution was used to convert EoL SW30 membrane to UF membrane. After this step, the resulting UF membrane was transformed into nanofiltration (NF) membrane by polyelectrolyte layer-by-layer (LbL) deposition. Gaining good NF membrane properties using EoL RO membrane as a substrate and bulk wastewater treatment chemicals in LbL deposition is the most valuable novelty in this study.

LbL assembly as a simple and controllable technique [25] can be used for coating the oppositely charged polyelectrolytes (polycation/polyanion) on substrate for the fabrication of a multilayer film. This ability is very practical for membrane modification. Thus, several studies have been done in this regard and many of them coated polyelectrolyte multilayers on porous substrates to prepare NF and RO membranes with satisfactory performance [26-33]. For example, membranes composed of five bilayers of poly(styrene sulfonate)/poly(allylamine hydrochloride) (PSS/PAH) on porous alumina substrates had a salt water flux of $35 \mathrm{~L} /\left(\mathrm{m}^{2} \mathrm{~h}\right)$ and $95 \%$ rejection of $\mathrm{MgCl}_{2}$ at 4.8 bar [26]. In another study, Jin et al. [27] coated 60 bilayers of polyvinyl amine/polyvinyl sulfate (PVA/PVS) on porous PAN/PET supports. They observed complete rejection of $\mathrm{MgSO}_{4}$ and $84 \%$ rejection of $\mathrm{NaCl}$ at 5 bar. The salt water permeability of the composite membrane was $0.1 \mathrm{~L} /\left(\mathrm{m}^{2} \mathrm{~h}\right.$ bar). $\mathrm{Ng}$ et al. prepared NF membranes by depositing five bilayers of poly(diallyldimethylammonium chloride) (PDADMAC) / PSS polyelectrolytes on poly(ether sulfone) (PES) membrane. Their results showed that water flux was $12 \mathrm{~L} /\left(\mathrm{m}^{2} \mathrm{~h}\right)$ and $\mathrm{NaCl}$ and $\mathrm{MgSO}_{4}$ rejections were 22.5 and $73.8 \%$, respectively, at 5 bar [32]. As another example, porous alumina membranes coated with 4.5-5 bilayers of PSS/PAH showed water fluxes of 37.5-75 L/(m² $\mathrm{h})$ and rejections of 88-97.6\% for $\mathrm{MgSO}_{4}$, and water fluxes of 45.8-104.2 $\mathrm{L} /\left(\mathrm{m}^{2} \mathrm{~h}\right)$ and rejections of $13-81 \%$ for $\mathrm{NaCl}$ at 4.8 bar [33]. 
In several studies, polyelectrolyte LbL deposition was used to reduce molecular weight cutoffs (MWCO) of porous membranes for fabricating tight UF membranes [34, 35]. Use of polyelectrolyte multilayers as membrane surface modification has received a lot of attention also in most recent studies [36-46].

The objective of this study was to investigate the performance of NF membranes prepared by polyelectrolyte multilayer coating on EoL RO membranes (after removing the PA layer) and compare the results with commercially available NF. The aim was also to use low-cost commercial polyelectrolytes in the preparation of multilayer coatings instead of bespoke and more expensive polyelectrolytes, as were used in the abovementioned studies.

\section{Material and methods}

\subsection{Materials}

The end-of-life spiral wound SW30 RO membrane with the trademark of DOW Filmtec was used in desalination process. The membrane is composed of three layers, a PA top selective layer, a poly(sulfone) (PSf) supporting layer, and a polyester base layer. After some pretreatment, the EoL membrane was used as the substrate for polyelectrolyte multilayer coating.

The performance of prepared membranes was compared with two commercial NF membranes of NF270 (Dow Filmtec) and Desal 5 DK (GE Osmonics).

The fouling of EoL membranes was cleaned with an alkaline cleaner, Ultrasil 110 (EcoLab Inc.). Ultrasil 110 consists of EDTA (5-10\%), $\mathrm{NaOH}(5-10 \%)$, sodium cumene sulfonate (1-5\%) and sodium dodecylbenzene sulfonate (1-5\%) [47].

$\mathrm{NaOCl}$ (11-15\% available chlorine) was purchased from Alfa Aesar Co., Germany, and used for the removal of the PA active layer of the EoL membrane.

Sodium chloride, $\mathrm{NaCl}(>99.0 \%)$, and magnesium sulfate, $\mathrm{MgSO}_{4}(>99.0 \%)$ were purchased from Fisher Scientific and Sigma Aldrich, respectively. All water used in the experiments was obtained from an ELGA Labwater Centra-R120 water purification unit equipped with a deionization cartridge $(\rho>15 \mathrm{M} \Omega \mathrm{cm})$.

The polyelectrolytes with high charge density were supplied by Kemira (Finland) and used without further purification. Their characteristics and chemical structures are shown in Table 2 and Fig. 1, respectively. 
Table 2. Characteristics of the polyelectrolytes used in this study.

\begin{tabular}{lllll}
\hline Product code & Type & $\mathrm{M}_{\mathrm{W}}(\mathrm{MDa})$ & Chemistry & $\mathrm{pK}$ \\
\hline SC498 & Cationic & $10-15$ & Cationic polyacrylamide & $-^{\mathrm{a}}$ \\
F2S & Cationic & $0.1-0.5$ & Polyethyleneimine & $10[48]$ \\
SA190 & Anionic & $5-10$ & Acrylate polymer & $4-5[49]$ \\
KE253 & Anionic & $0.03-0.06$ & Acrylate copolymer & $4-5[49]$ \\
\hline
\end{tabular}

${ }^{a} \mathrm{SC} 498$ is quaternary ammonium $\mathrm{PE}$ and due to full quaternization, the cationic charge will remain over the whole $\mathrm{pH}$ range, so there is no $\mathrm{pK}_{\mathrm{b}}$ (i.e. no dissociation or de/protonation)

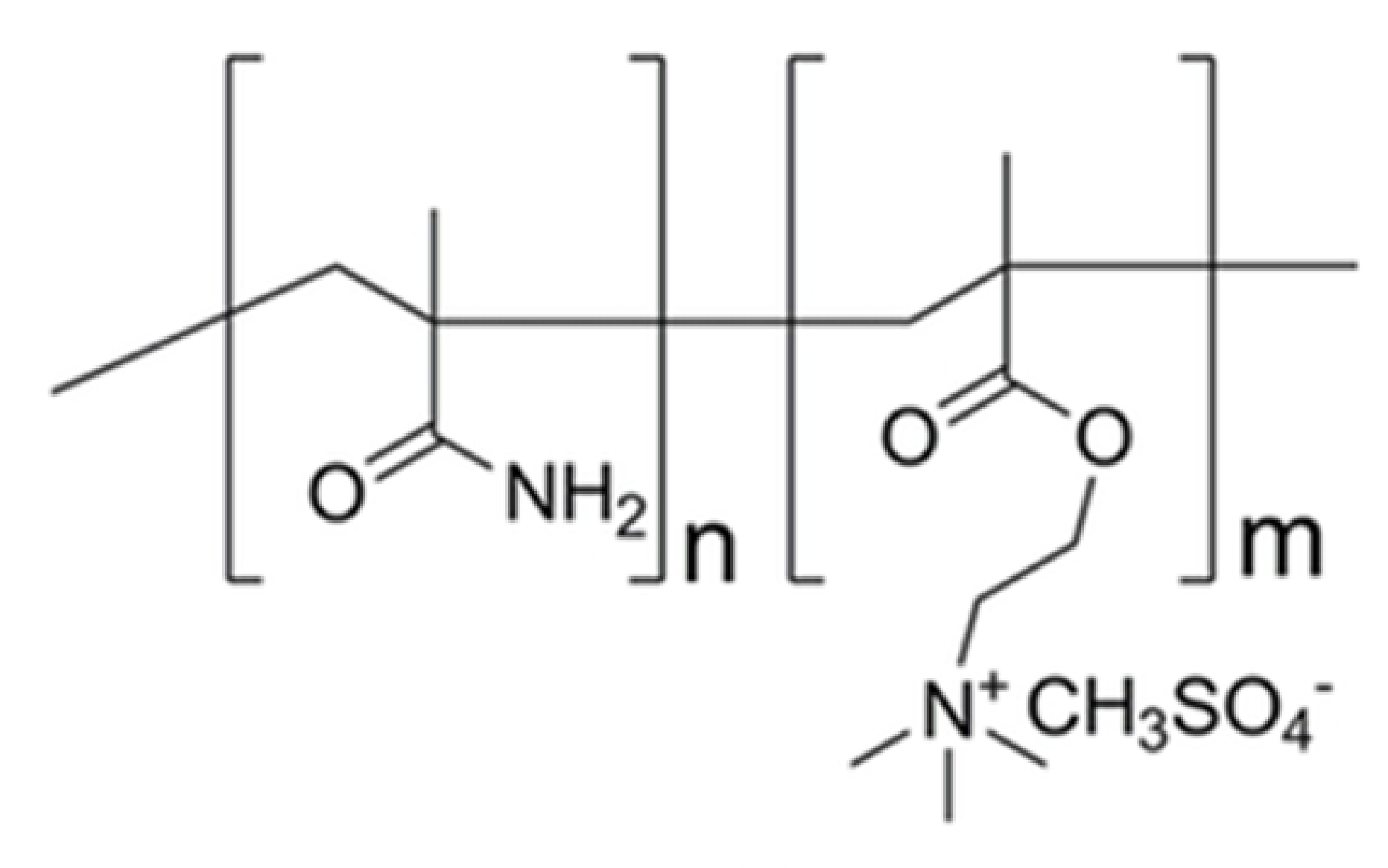

SC498<smiles>CCC(C)C(=O)O[Na]</smiles>

SA190<smiles>CCCNCCN(CCN)CCN(CCNCCN)CCN(CCNC)CCN(CCN)CCN</smiles>

F2S<smiles>CC(C)(C)CC(C(=O)O)C(C)(C)C(C)(C)C(C(=O)[O-])C1C(C(=O)O)[C@H]2CCCCC12C</smiles>

KE253

Fig. 1. Chemical structures of the polyelectrolytes used in this study.

\subsection{Pretreatment of EoL membranes before $\mathrm{LbL}$ deposition}

Initially, EoL SW30 RO membranes were completely soaked in $1 \mathrm{v} / \mathrm{v} \%$ Ultrasil 110 solution (pH: 12.3) without stirring for removing the fouling layer from the membrane surface. After 24 hours, the membranes were withdrawn from the Ultrasil 110 solution and rinsed with deionized water. Then, the PA active layer was removed by completely soaking in $\mathrm{NaOCl}$ solution at atmospheric pressure and under stirring condition. The $\mathrm{pH}$ of the $1.3 \mathrm{wt} \% \mathrm{NaOCl}$ solution was 12.1 and the solution was protected from UV light to limit $\mathrm{NaOCl}$ deterioration.

The $\mathrm{NaOCl}$ exposure intensity was in the range of 13,000 to $240,500 \mathrm{ppm}$ h. To achieve the desired exposure intensity, the concentration of the $\mathrm{NaOCl}$ was kept constant at 13,000 ppm $(1.3 \mathrm{wt} \%)$ and the exposure time was varied.

The membranes were rinsed with deionized water at the end of pretreatment and kept in pure water until pure water permeability (PWP) was measured. 


\subsection{Water permeability and salt rejection of substrates (pretreated EoL membranes)}

Measurement of pure water permeability of substrates $\left(\mathrm{PWP}_{\mathrm{S}}\right)$ and their salt rejection was carried out using a dead-end Amicon stirred cell (model 8400) with a feed volume of $300 \mathrm{~mL}$. $\mathrm{PWP}_{\mathrm{S}}\left(\mathrm{L} /\left(\mathrm{m}^{2} \mathrm{~h}\right.\right.$ bar) was defined as:

$\mathrm{PWP}_{\mathrm{S}}=\frac{\mathrm{V}}{\mathrm{S} \times \mathrm{t} \times \mathrm{p}}$

where $\mathrm{V}$ is the total volume of permeate during the sampling time interval $\mathrm{t}$ at steady state, $\mathrm{S}$ is the effective membrane area in the module, and $\mathrm{p}$ is the feed pressure. $\mathrm{S}$ and $\mathrm{p}$ were $0.0038 \mathrm{~m}^{2}$ and $4 \mathrm{bar}$, respectively, in all UF tests. The salt rejection of substrate $\left(\mathrm{R}_{\mathrm{S}} \%\right)$ was defined as:

$\mathrm{R}_{\mathrm{S}} \%=\left(1-\frac{2 \mathrm{C}_{\mathrm{P}}}{\mathrm{C}_{\mathrm{F}}+\mathrm{C}_{\mathrm{R}}}\right) \times 100$

where $C_{P}$ is the solute concentration in the permeate and $C_{F}$ and $C_{R}$ are the solute concentrations in the feed and retentate, respectively. After measuring PWP and salt rejection, all membranes were soaked in deionized water.

\subsection{Polyelectrolyte multilayer coatings}

Polyelectrolyte multilayer coating can be done using five distinct techniques, namely: (1) dipping, (2) spinning, (3) spraying, (4) electromagnetic, and (5) fluidic assembly [50, 51]. In this study, the fluidic assembly method was used to deposit PE on EoL membranes after removing their PA skin layer.

After placing the membrane sample in a cell, a gear pump was used to circulate PE solutions from the two feed tanks over the membrane. Each of the feed tanks contained one litter of $1 \mathrm{~g} / \mathrm{L} \mathrm{PE}$ and $0.05 \mathrm{M} \mathrm{NaCl}$.

The streaming potential test showed that substrates have a negative surface charge, so cationic polyelectrolyte solution was first circulated over the membrane with a flow rate of $180 \mathrm{~mL} / \mathrm{min}$ and a pressure of 0.2 bar for $4 \mathrm{~min}$. For the completion of polyelectrolyte deposition, the outlet was closed, and the circulation stopped for $1 \mathrm{~min}$. Following this step, the remaining PE solution was drained, and the membrane surface was washed with $0.05 \mathrm{M} \mathrm{NaCl}$ solution to remove loosely bound polyelectrolytes. 
The next PE deposition was begun after rinsing the flow channel with the deionized water to reach pure water conductivity. Anionic polyelectrolyte solution was deposited in the same manner and the whole process was cycled until reaching the desired number of bilayers, which was eight in this study. The LbL deposition was carried out at a temperature of $23 \square$.

\subsection{Permeability and salt rejection of LbL-coated membrane}

The performance of LbL-coated membranes was evaluated in a cross-flow filtration setup with four parallel flat sheet membrane cells, as shown schematically in Fig. 2. The effective membrane area of each cell was $0.001 \mathrm{~m}^{2}$. Initially, all LbL-coated membranes were subjected to stabilization conditions with pure water at a feed pressure of 15 bar. Then, the performances of LbL-coated membranes were evaluated by filtering two aqueous $\mathrm{NaCl}$ and $\mathrm{MgSO}_{4}$ solutions ( $500 \mathrm{ppm}$ ) at two feed pressures of 5 and 10 bar. All tests were accomplished at a temperature of $25 \pm 2{ }^{\circ} \mathrm{C}$ and a cross-flow velocity of 0.3 $\mathrm{m} / \mathrm{s}$ for at least $30 \mathrm{~min}$.

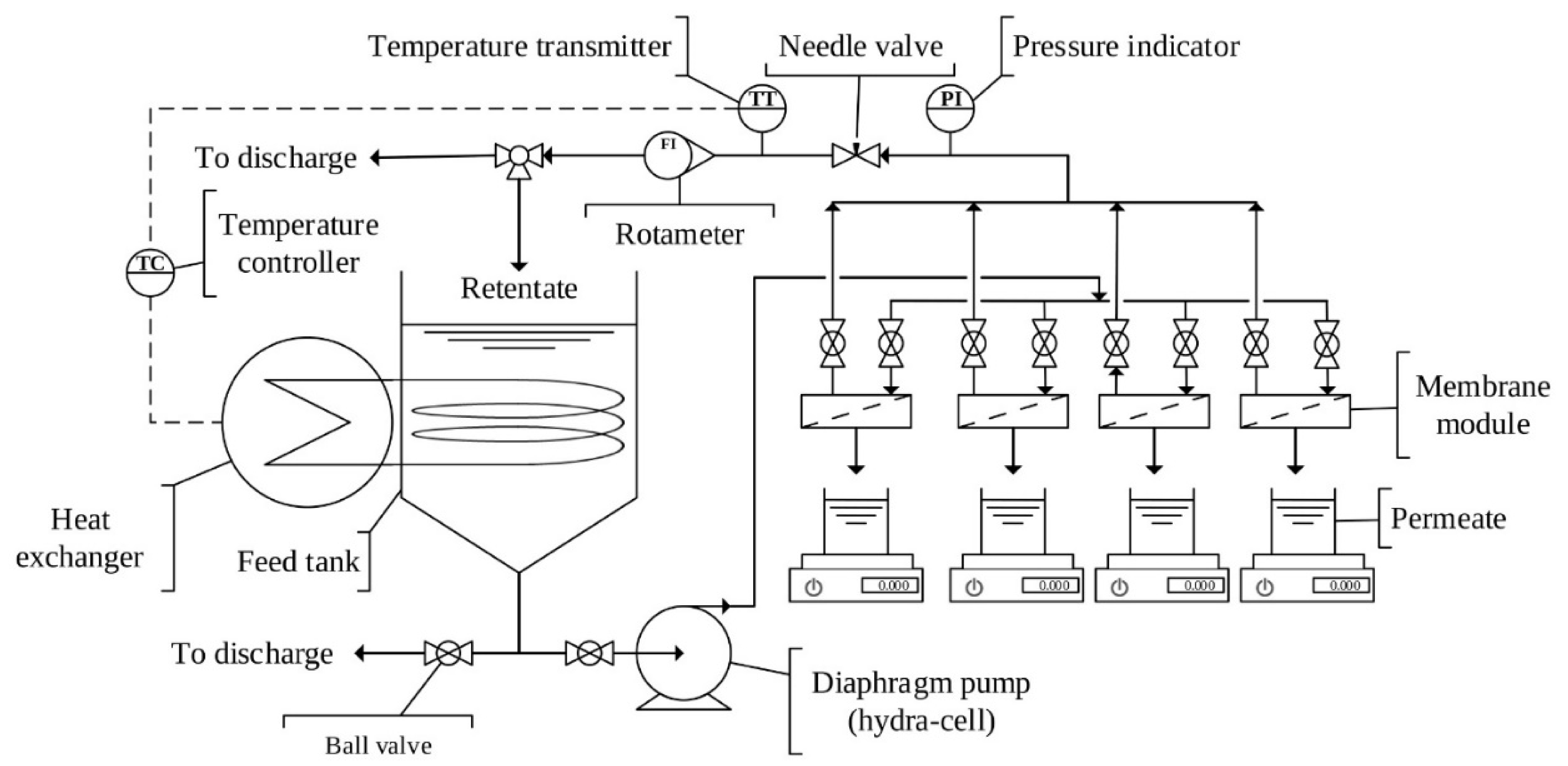

Fig. 2. Schematic diagram of cross-flow filtration setup used for evaluation of LbL-coated membranes

Eq. 1 was also used for calculating pure water permeability after LbL coating (PWP) and salt water permeability (SWP). The salt rejection in cross-flow filtration setup, $\mathrm{R} \%$, was defined as:

$\mathrm{R} \%=\left(1-\mathrm{C}_{\mathrm{P}} / \mathrm{C}_{\mathrm{F}}\right) \times 100$

The parameters of PWP, SWP, and R\% without subscript are related to LbL-coated membranes. 


\subsection{Analyses}

The solution and membrane samples were analyzed using several methods to evaluate the effect of pretreatment and polyelectrolyte multilayer coatings. The analyses performed are listed in Table 3 .

Table 3. Analyses for the evaluation of pretreatment and polyelectrolyte multilayer coatings.

\begin{tabular}{lll}
\hline Analysis & Method & Equipment \\
\hline $\mathrm{pH}$ & - & Metrohm 744 pH meter \\
Conductivity & - & Knick konduktometer 703 \\
Contact angle & Sessile drop method & KSV CAM 101 and computer program CAM 2008 \\
Surface charge & Steaming current & SurPASS electrokinetic analyzer from Anton Paar \\
FTIR & Universal attenuated total & Perkin Elmer FTIR Frontier Spectrometer \\
& reflectance (UATR) & \\
SEM & - & JEOL (JSM-5800) \\
\hline
\end{tabular}

\section{Results and discussion}

\subsection{Substrate properties before $L b L$ coating}

\subsubsection{Water permeability and salt rejections of substrates}

$\mathrm{PWP}_{\mathrm{S}}$ and $\mathrm{NaCl}$ rejection of EoL RO membranes were measured at different $\mathrm{NaOCl}$ exposure intensities. Most of experiments were repeated at least three times. The PWP of samples before exposure to $\mathrm{NaOCl}$ were negligible. Therefore, their salt rejections could not be measured. For the samples after $1 \mathrm{~h}$ exposure to $\mathrm{NaOCl}(13,000 \mathrm{ppm} \mathrm{h})$, the $\mathrm{PWP}_{\mathrm{S}}, \mathrm{NaCl} \mathrm{RS} \%$ and $\mathrm{MgSO}_{4} \mathrm{R}_{\mathrm{S}} \%$ were $3.7 \mathrm{~L} /\left(\mathrm{m}^{2} \mathrm{~h}\right.$ bar), $64 \%$ and $76 \%$, respectively. Due to a higher degradation level of the PA layer at a higher $\mathrm{NaOCl}$ exposure intensity, $\mathrm{PWP}_{\mathrm{S}}$ increases and reaches almost a plateau after $15 \mathrm{~h}(195,000 \mathrm{ppm} \mathrm{h})$. This can be regarded as almost complete removal of the PA active layer at a higher $\mathrm{NaOCl}$ exposure intensity. After $18.5 \mathrm{~h}$ contact with $\mathrm{NaOCl}(240,500 \mathrm{ppm} h)$, the $\mathrm{PWP}_{\mathrm{S}}$ and $\mathrm{R}_{\mathrm{S}} \%$ of samples reached $51 \mathrm{~L} /\left(\mathrm{m}^{2} \mathrm{~h}\right.$ bar) and almost zero, respectively. These results can be compared with those studies that have investigated the effect of $\mathrm{NaOCl}$ on EoL SWRO membrane (see Table 1). In our case the PWPs was significantly higher than $9 \mathrm{~L} /\left(\mathrm{m}^{2} \mathrm{~h}\right.$ bar $)$ achieved by Lawler et al. [22] with 300,000 ppm h of $\mathrm{NaOCl}$ exposure $(\mathrm{NaCl}$ rejection $<1 \%)$. 


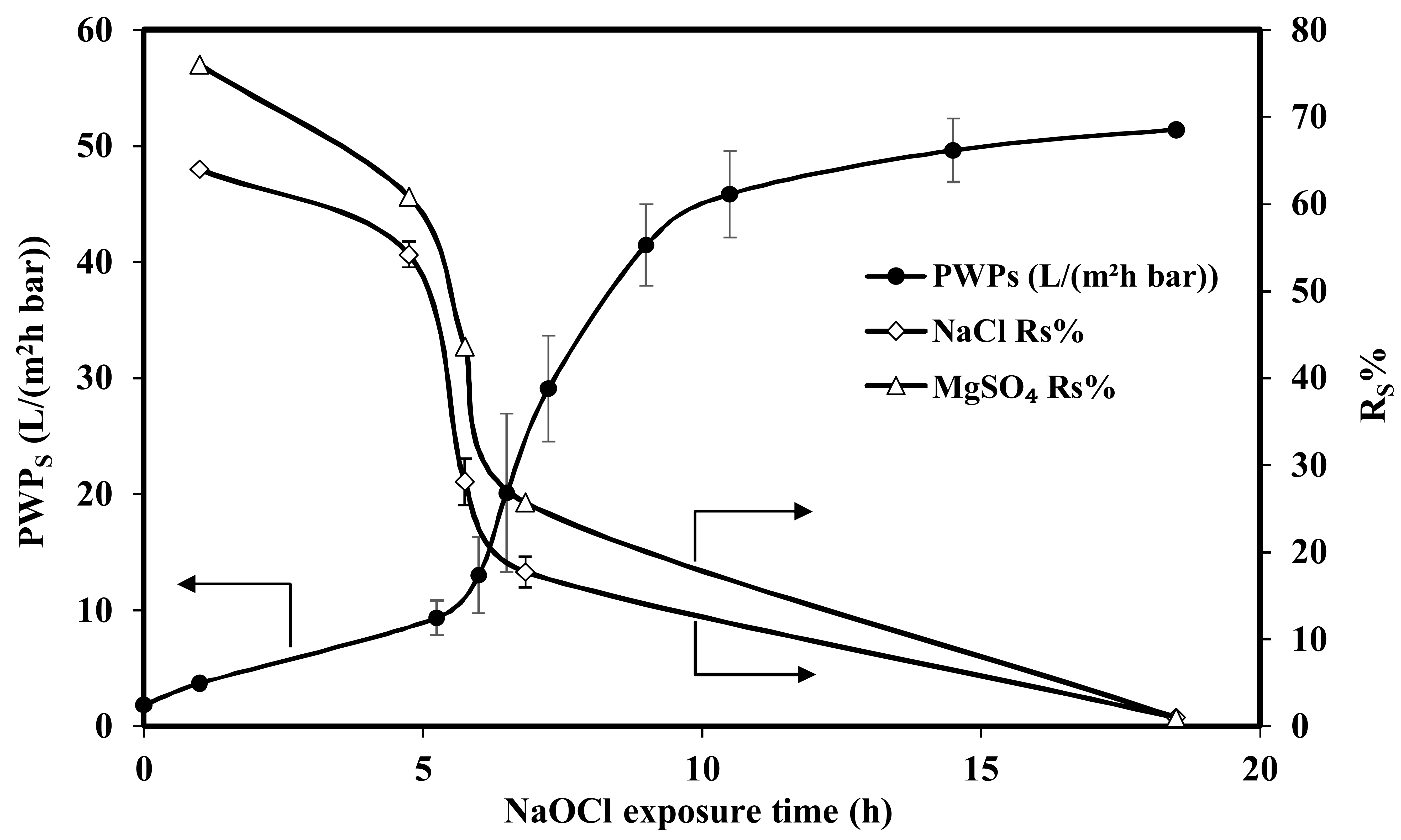

Fig. 3. Pure water permeability, $\mathrm{NaCl}$ and $\mathrm{MgSO}_{4}$ rejection of substrate (EoL membranes) after exposure to $\mathrm{NaOCl}$ solution with concentration of 13,000 ppm (feed pressure $=4$ bar). The error bars represent standard deviation.

\subsubsection{ATR-FTIR spectroscopy of EoL RO membranes after exposure to $\mathrm{NaOCl}$ solution}

To better observe the effect of increasing $\mathrm{NaOCl}$ exposure intensity on the PA layer of EoL membranes, eight samples exposed to $\mathrm{NaOCl}$ at $1,5.75,6.5,7.25,9$, and $18.5 \mathrm{~h}$ were selected for investigation by ATR-FTIR spectroscopy.

The FTIR spectra of the abovementioned samples and a poly(sulfone) (PSf) membrane (as benchmark) are shown in Fig. 4. The difference between EoL1 and EoL2 in Fig. 4 is that EoL1 was analyzed without any cleaning treatment, but EoL2 was rinsed with deionized water after 24 hours of immersion in the Ultrasil 110 solution. All the spectra were normalized to band at $1487 \mathrm{~cm}^{-1}$, that is for aromatic in-plane ring bend stretching vibrations of the PSf support layer, which remains constant during the degradation of the PA layer. The spectra of EoL membranes show peaks at 1664 and 1542 $\mathrm{cm}^{-1}$, corresponding to amide I and amide II bands, respectively, associated with $\mathrm{C}=\mathrm{O}$ stretching and $\mathrm{N}-\mathrm{H}$ plane bending. The peak at $1610 \mathrm{~cm}^{-1}$ is representative of the $\mathrm{C}=\mathrm{C}$ stretching vibrations from the aromatic amide bonds [52]. These results are consistent with those observed in other studies [16, $18,22,53]$. 


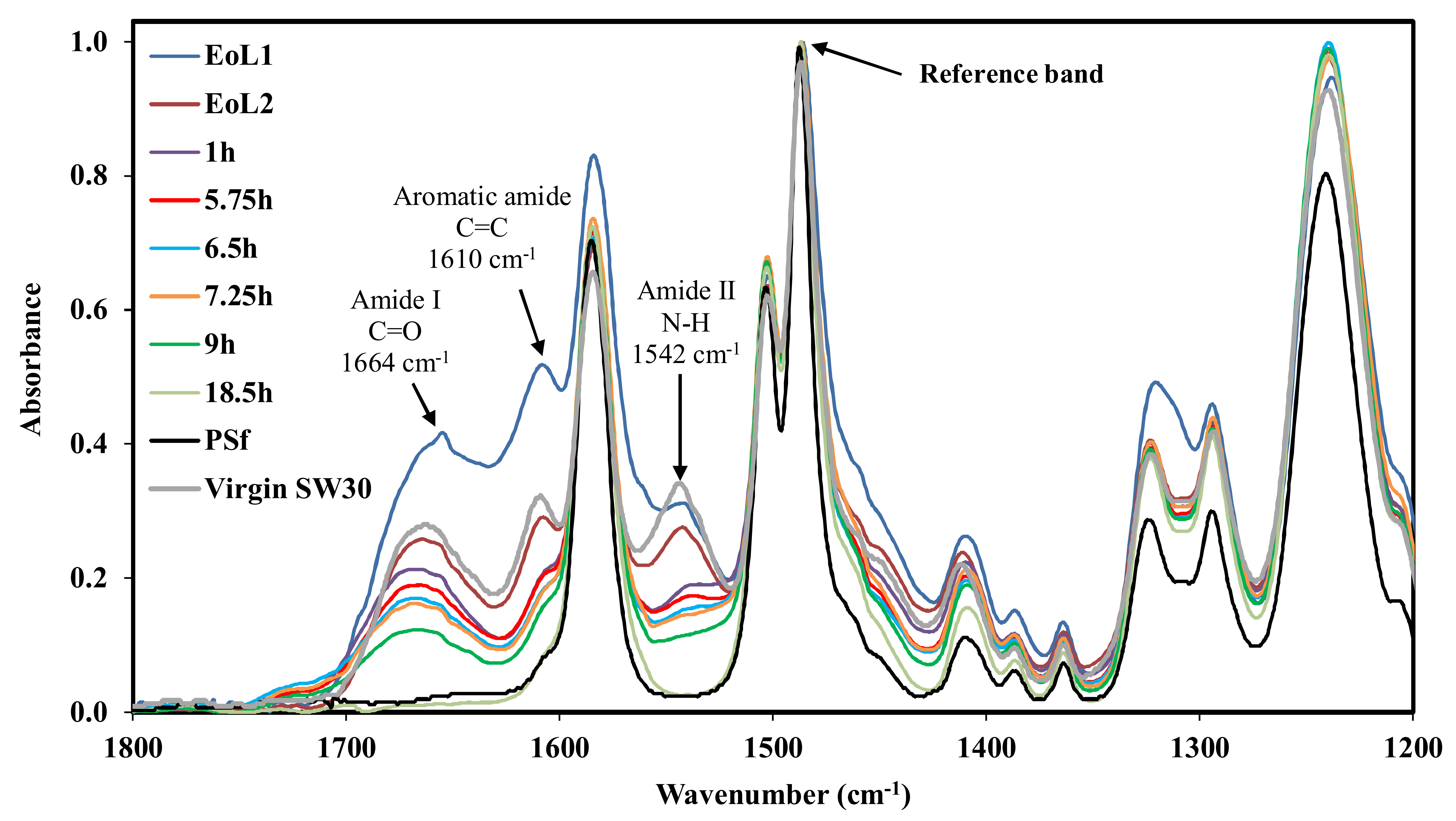

Fig. 4. ATR-FTIR spectra of EoL membranes before and after different $\mathrm{NaOCl}$ exposure times and a PSf membrane.

By comparing spectrum of EoL1, EoL2 and virgin SW30 sample, it can be seen that foulants covered and decreased the sharpness of the polyamide peaks (like Amide I and II peaks at $1664 \mathrm{~cm}^{-1}$ and 1542 $\mathrm{cm}^{-1}$ wavelength). The peaks of fouled membrane after cleaning (EoL2) is like virgin membrane, which indicates that Ultrasil treatment had only little effect on the polyamide. The intensity of polyamide peaks progressively reduced with the increase in $\mathrm{NaOCl}$ exposure intensity, and they became nearly the same as PSf peaks after $18.5 \mathrm{~h}$ due to the near-complete removal of the polyamide layer.

\subsubsection{SEM images}

The contaminants and foulants on the surface of the EoL1 membrane sample is visible in Fig. 5a that has an amorphous shape (non-crystalline) and lesser amounts of dispersed structure. To reveal the type of foulants in both structures, two Energy-dispersive X-ray spectroscopy (EDS) spectra were taken from both places, as illustrated in Fig. 6. A spectrum of amorphous shape in Fig. 6a shows a high level of $\mathrm{Ca}, \mathrm{O}$ and $\mathrm{C}$, which indicates that the deposited material was probably calcium carbonate $\left(\mathrm{CaCO}_{3}\right)$ [54]. On the other side, high level of $\mathrm{C}, \mathrm{O}$ and $\mathrm{S}$ can be seen in spectrum of dispersed structure in Fig. 6b. However, based on the data presented in two spectra, the foulants on the EoL membrane surface included mixture of organic matter and inorganic materials. 
After the cleaning of the EoL membrane with Ultrasil solution, the SEM image in Fig. $5 b$ shows less contaminants compared to Fig. 5a. Based on the EDS results, the weight percentage of calcium on the surface of the EoL2 sample is much less than on the EoL1 sample.

The surface SEM images of the EoL membrane after exposure to the $\mathrm{NaOCl}$ solution for $7.25 \mathrm{~h}$ (Fig. 5c) is similar to that on a virgin SW membrane (Fig. 5e), but according to the FTIR results in Fig. 4, we know that some bonds of the polyamide are chemically degraded, which is not detectable in the SEM image. The surface of the EoL membrane after 18.5 hours' contact with the NaOCl solution (Fig. 5d) does not differ from PSf (Fig. 5f). This similarity was also observed in the FTIR results (Fig. 4).
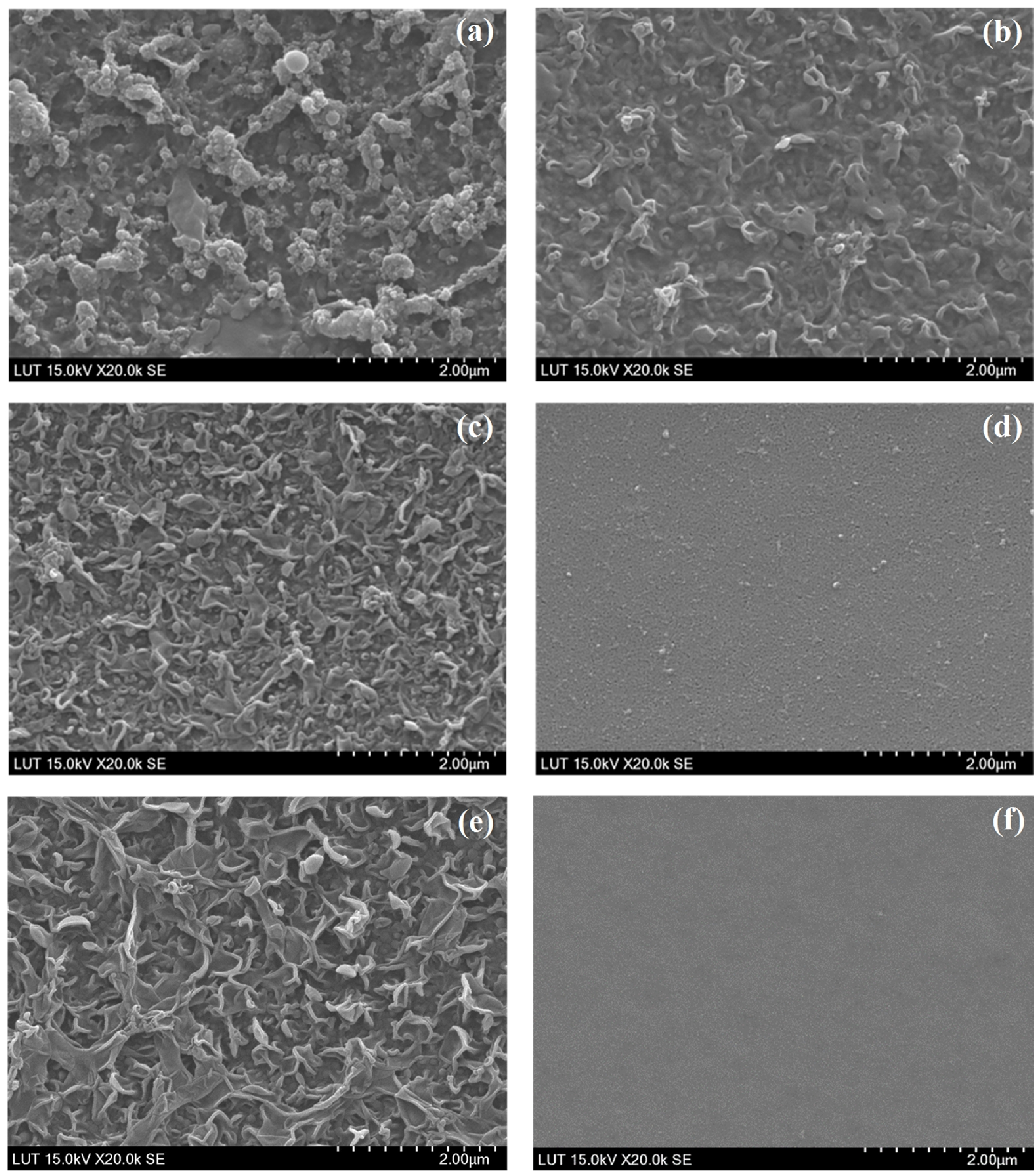

Fig. 5. The surface SEM images of EoL SW membranes after (a) no operation, (b) cleaning with Ultrasil 110 solution, (c) contact with $\mathrm{NaOCl}$ solution for $7.25 \mathrm{~h}$, (d) contact with $\mathrm{NaOCl}$ solution for $18.5 \mathrm{~h}$, (e) virgin SW membrane, and (f) virgin PSf membrane. 

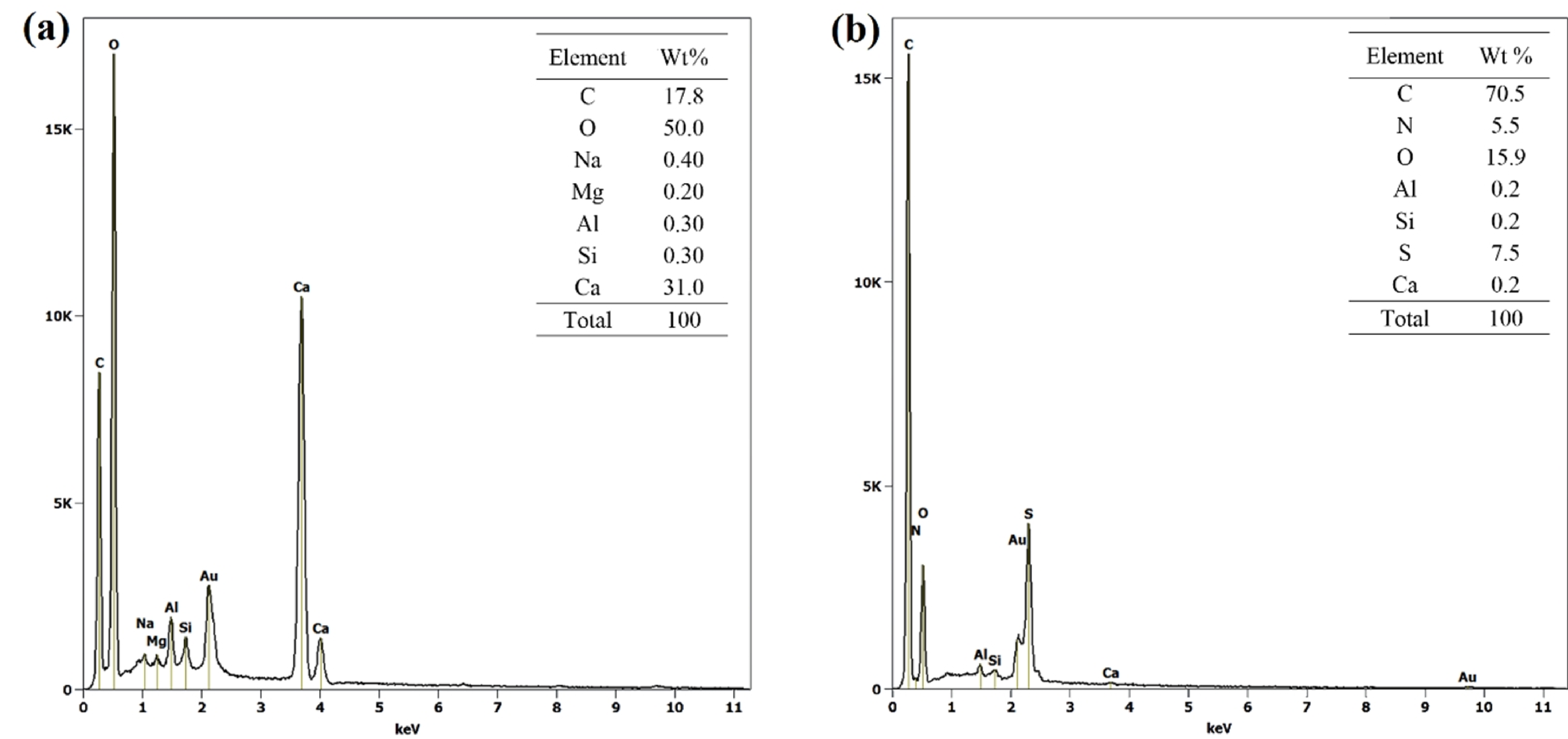

Fig. 6. EDS spectra from two places of EoL1 sample surface, (a) amorphous shape and (b) dispersed structure.

\subsubsection{Surface charge}

The surface charge of EoL membranes was determined before LbL coating. As shown in Fig. 7, the surface charge of all samples was negative after exposure to $\mathrm{NaOCl}$, although it became more negative by increasing $\mathrm{NaOCl}$ exposure time for almost all $\mathrm{pH}$ levels, which corresponds with previous observations [55-57]. Therefore, LbL coating was started with cationic polyelectrolyte.

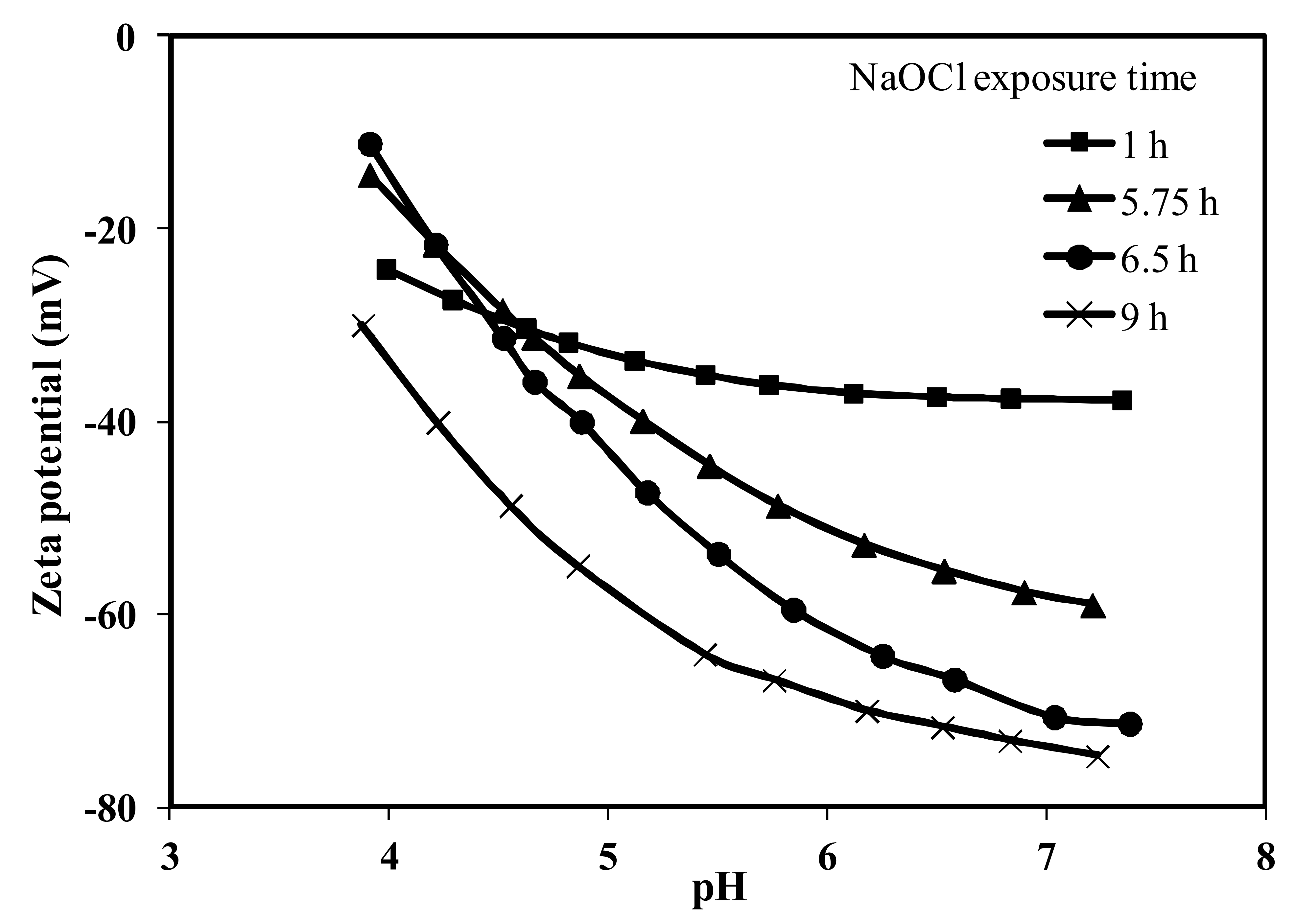

Fig. 7. The surface charge of EoL membranes after exposure to $\mathrm{NaOCl}$ solution (before LbL deposition).

\subsection{Properties of LbL-coated membranes}

\subsubsection{Permeabilities and salt rejections of LbL-coated membranes}

Seven EoL membranes with PWPs from 3.7 to $48.5 \mathrm{~L} /\left(\mathrm{m}^{2} \mathrm{~h}\right.$ bar) were coated with (SC498/SA190)8. Their PWP, SWP, and $\mathrm{MgSO}_{4}$ rejection were measured in the cross-flow filtration setup at a feed pressure of 10 bar and are shown in Table 4 and Fig. 8. 
Table 4. Permeability and $\mathrm{MgSO}_{4}$ rejections of NF membranes composed of (SC498/SA190) $)_{8}$ on substrates with different $\mathrm{PWP}_{\mathrm{S}},\left(\mathrm{C}_{\mathrm{F}}=500 \mathrm{ppm}\right)$.

\begin{tabular}{cccc}
\hline $\begin{array}{c}\mathrm{PWP} \\
\mathrm{L} /\left(\mathrm{m}^{2} \mathrm{~h} \text { bar }\right)\end{array}$ & $\begin{array}{c}\mathrm{PWP} \\
\mathrm{L} /\left(\mathrm{m}^{2} \mathrm{~h} \text { bar }\right)\end{array}$ & $\begin{array}{c}\mathrm{SWP} \\
\mathrm{L} /\left(\mathrm{m}^{2} \mathrm{~h} \text { bar }\right)\end{array}$ & $\begin{array}{c}\mathrm{MgSO}_{4} \\
\mathrm{R} \%\end{array}$ \\
\hline 3.7 & 3.2 & 3.3 & 96.6 \\
11.5 & 9.2 & 8.1 & 90.7 \\
20.0 & 14.9 & 13.7 & 89.1 \\
29.5 & 14.6 & 14.5 & 91.4 \\
33.0 & 13.8 & 19.6 & 66.0 \\
42.5 & 10.9 & 10.9 & 17.3 \\
48.5 & 8.5 & 8.8 & 16.6 \\
\hline
\end{tabular}

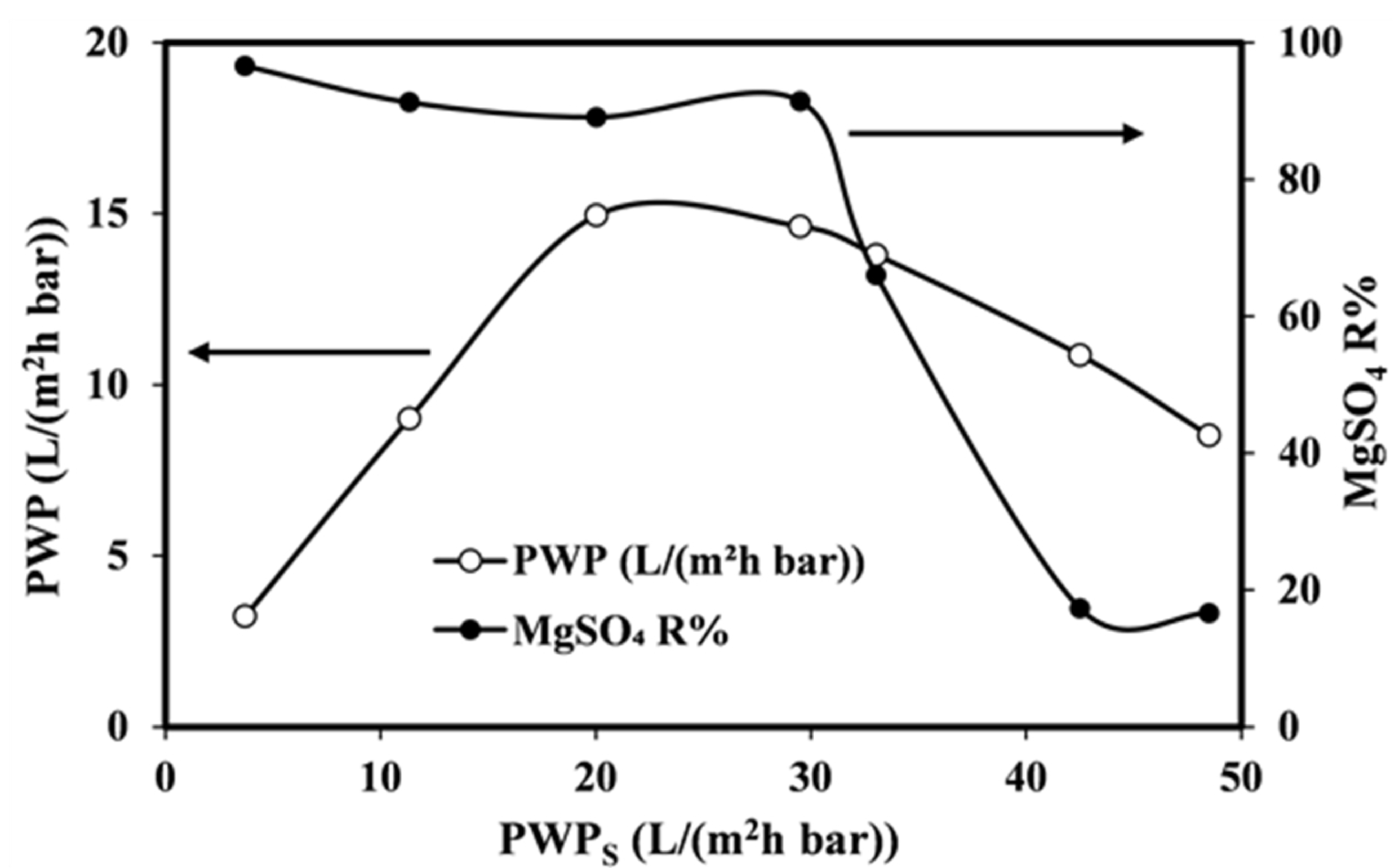

Fig. 8. PWP and $\mathrm{MgSO}_{4}$ rejections of LbL-coated membranes composed of (SC498/SA190) $)_{8}$ on different substrates as a function of $\mathrm{PWP}_{\mathrm{S}}$

The coverage of support by PE is evident from the decrease in water permeability after the deposition of eight bilayers of SC498/SA190. The results show that PWP first increased and then reduced with the increase of PWPs. The rejection of $\mathrm{MgSO}_{4}$ stayed above $90 \%$ until the support material pure water permeability exceeded $30 \mathrm{~L} /\left(\mathrm{m}^{2} \mathrm{~h}\right.$ bar).

Malaisamy and Bruening also observed such changes in LbL-coated membrane permeability with different MWCO of substrates [28]. It is obvious that substrates with higher PWPs have larger pores. By increasing the pore size, instead of absorbing the PE at the surface, it penetrates into pores and eventually blocks them. Thus, PWP decreases.

The LbL-coated membranes with PWP of close to or more than $10 \mathrm{~L} /\left(\mathrm{m}^{2} \mathrm{~h}\right.$ bar) and $\mathrm{MgSO}_{4}$ rejection of near or more than $90 \%$ were chosen to constrict the selection area of substrates for LbL coating. The range of PWPS corresponding to the above conditions is 10 to $30 \mathrm{~L} /\left(\mathrm{m}^{2} \mathrm{~h}\right.$ bar $)$, which is the middle 
area presented in Figs 3 and 8. Therefore, three groups of EoL membranes with PWPs of about 10, 20 , and $30 \mathrm{~L} /\left(\mathrm{m}^{2} \mathrm{~h}\right.$ bar) (in the following tables noted as $\mathrm{A}, \mathrm{B}$, and $\mathrm{C}$, respectively) were prepared to convert them to NF membranes by LbL coating. Subsequently, the membranes with almost equal $\mathrm{PWP}_{\mathrm{S}}$ were selected in order to compare the performance.

The performance of coated membranes with three different compositions of PE bilayers are presented in Table 5. Because of the large number of tests, just three were repeated randomly. Some of the best results were obtained for coated membrane B2-(SC498/KE253) 8 with salt water permeability of 11.2 $\mathrm{L} /\left(\mathrm{m}^{2} \mathrm{~h}\right.$ bar) and $93.9 \%$ rejection of $\mathrm{MgSO}_{4}$. Excellent rejection of divalent ions but rather low permeability in group A may be also due to only partial removal of EoL membrane PA layer.

Table 5. Permeabilities (L/( $\mathrm{m}^{2} \mathrm{~h}$ bar) ) and salt rejections of coated membranes composed of (SC498/SA190) 8 , $(\mathrm{SC} 498 / \mathrm{KE} 253)_{8},(\mathrm{~F} 2 \mathrm{~S} / \mathrm{SA} 190)_{8}$, and (SC498/SA190) ${ }_{8} \mathrm{SC}_{4} 98$ on different substrates ${ }^{\mathrm{a}}$.

\begin{tabular}{|c|c|c|c|c|c|c|c|}
\hline \multirow{2}{*}{$\begin{array}{l}\text { Substrate } \\
\text { Code }\end{array}$} & \multirow{2}{*}{ PWPs } & \multirow{2}{*}{ PE bilayers } & \multirow{2}{*}{ PWP } & \multicolumn{2}{|c|}{$\mathrm{NaCl}$} & \multicolumn{2}{|c|}{$\mathrm{MgSO}_{4}$} \\
\hline & & & & SWP & $\mathrm{R} \%$ & SWP & $\mathrm{R} \%$ \\
\hline $\mathrm{A} 1^{\mathrm{b}}$ & $12.2 \pm 0.7$ & $(\mathrm{SC} 498 / \mathrm{SA} 190)_{8}$ & $8.7 \pm 0.5$ & $\begin{array}{c}8.1 \pm 0.04 \\
{[8.2 \pm 0.1]}\end{array}$ & $\begin{array}{c}82.4 \pm 1.0 \\
{[77.1 \pm 1.0]}\end{array}$ & $\begin{array}{c}8.4 \pm 0.3 \\
{[8.3 \pm 0.4]}\end{array}$ & $\begin{array}{c}90.2 \pm 0.5 \\
{[86.9 \pm 0.7]}\end{array}$ \\
\hline A2 & 12.4 & $(\mathrm{SC} 498 / \mathrm{KE} 253)_{8}$ & 8.9 & $\begin{array}{c}9.0 \\
{[8.9]}\end{array}$ & $\begin{array}{c}88.8 \\
{[84.6]}\end{array}$ & $\begin{array}{c}7.7 \\
{[7.9]}\end{array}$ & $\begin{array}{c}96.3 \\
{[94.5]}\end{array}$ \\
\hline A3 & 11.6 & $(\mathrm{~F} 2 \mathrm{~S} / \mathrm{SA} 190)_{8}$ & 8.5 & $\begin{array}{c}7.7 \\
{[7.5]}\end{array}$ & $\begin{array}{c}91.5 \\
{[88.3]}\end{array}$ & $\begin{array}{c}8.0 \\
{[8.1]}\end{array}$ & $\begin{array}{c}96.3 \\
{[95.8]}\end{array}$ \\
\hline A4 & 11.7 & $(\mathrm{SC} 498 / \mathrm{SA} 190)_{8} \mathrm{SC} 498$ & 6.5 & $\begin{array}{c}6.7 \\
{[6.3]}\end{array}$ & $\begin{array}{c}85.3 \\
{[79.1]}\end{array}$ & $\begin{array}{c}6.0 \\
{[5.3]}\end{array}$ & $\begin{array}{c}92.1 \\
{[89.6]}\end{array}$ \\
\hline B1 & 20.0 & $(\mathrm{SC} 498 / \mathrm{SA} 190)_{8}$ & 14.9 & $\begin{array}{c}14.4 \\
{[15.0]}\end{array}$ & $\begin{array}{c}43.6 \\
{[33.5]}\end{array}$ & $\begin{array}{c}13.7 \\
{[14.0]}\end{array}$ & $\begin{array}{c}89.1 \\
{[86.9]}\end{array}$ \\
\hline B2 & 17.7 & $(\mathrm{SC} 498 / \mathrm{KE} 253)_{8}$ & 12.3 & $\begin{array}{c}12.9 \\
{[13.0]}\end{array}$ & $\begin{array}{c}60.6 \\
{[56.4]}\end{array}$ & $\begin{array}{c}11.2 \\
{[11.5]}\end{array}$ & $\begin{array}{c}93.9 \\
{[91.8]}\end{array}$ \\
\hline B3 & 17.1 & $(\mathrm{~F} 2 \mathrm{~S} / \mathrm{SA} 190)_{8}$ & 9.5 & $\begin{array}{c}8.7 \\
{[9.5]}\end{array}$ & $\begin{array}{c}87.6 \\
{[81.1]}\end{array}$ & $\begin{array}{c}9.0 \\
{[9.1]}\end{array}$ & $\begin{array}{c}98.3 \\
{[97.4]}\end{array}$ \\
\hline$B 4^{b}$ & $20.1 \pm 1.2$ & $(\mathrm{SC} 498 / \mathrm{SA} 190)_{8} \mathrm{SC} 498$ & $13.9 \pm 0.1$ & $\begin{array}{c}14.1 \pm 0.6 \\
{[14.0 \pm 0.6]}\end{array}$ & $\begin{array}{c}55.4 \pm 2.8 \\
{[47.9 \pm 2.6]}\end{array}$ & $\begin{array}{c}13.2 \pm 0.6 \\
{[11.7 \pm 0.6]}\end{array}$ & $\begin{array}{c}91.0 \pm 1.5 \\
{[87.8 \pm 2.1]}\end{array}$ \\
\hline $\mathrm{C} 1$ & 29.5 & $(\mathrm{SC} 498 / \mathrm{SA} 190)_{8}$ & 14.6 & 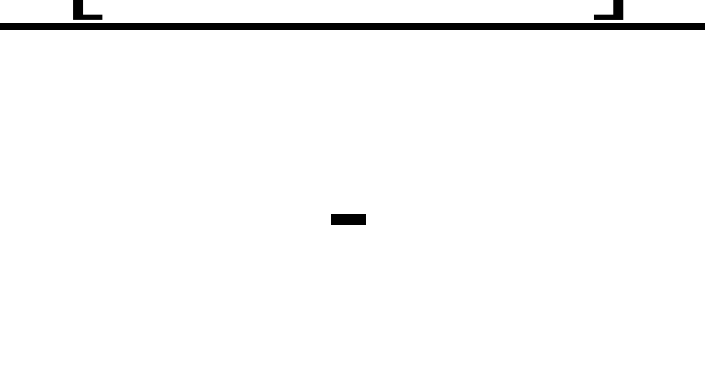 & 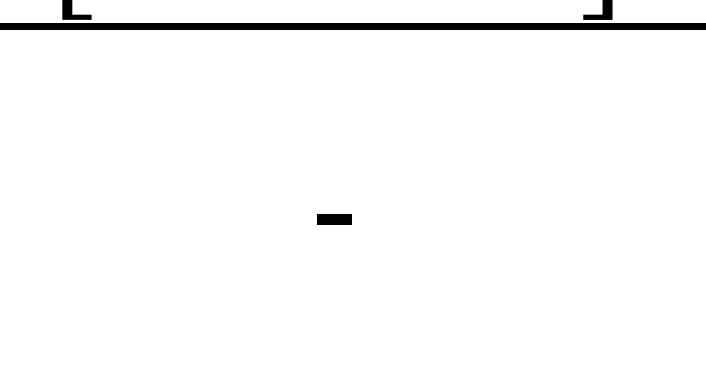 & $\begin{array}{c}14.5 \\
{[15.4]}\end{array}$ & $\begin{array}{c}91.4 \\
{[91.0]}\end{array}$ \\
\hline $\mathrm{C} 2$ & 28.1 & $(\mathrm{SC} 498 / \mathrm{KE} 253)_{8}$ & 15.0 & $\begin{array}{c}14.7 \\
{[15.6]}\end{array}$ & $\begin{array}{c}56.4 \\
{[53.5]}\end{array}$ & $\begin{array}{c}14.1 \\
{[15.1]}\end{array}$ & $\begin{array}{c}89.3 \\
{[87.8]}\end{array}$ \\
\hline$C 3^{b}$ & $30.0 \pm 2.0$ & $(\mathrm{~F} 2 \mathrm{~S} / \mathrm{SA} 190)_{8}$ & $16.7 \pm 2.0$ & $\begin{array}{c}13.4 \pm 0.1 \\
{[13.7 \pm 0.5]}\end{array}$ & $\begin{array}{c}75.9 \pm 4.4 \\
{[75.4 \pm 2.4]}\end{array}$ & $\begin{array}{c}13.4 \pm 0.3 \\
{[13.4 \pm 0.2]}\end{array}$ & $\begin{array}{c}90.8 \pm 0.8 \\
{[92.0 \pm 2.0]}\end{array}$ \\
\hline $\mathrm{C} 4$ & 29.7 & $(\mathrm{SC} 498 / \mathrm{SA} 190)_{8} \mathrm{SC} 498$ & 14.5 & $\begin{array}{c}19.14 \\
{[18.73]} \\
\end{array}$ & $\begin{array}{c}36.2 \\
{[41.0]} \\
\end{array}$ & $\begin{array}{c}14.2 \\
{[15.1]} \\
\end{array}$ & $\begin{array}{c}91.5 \\
{[90.1]} \\
\end{array}$ \\
\hline
\end{tabular}

${ }^{a}$ Numbers inside the brackets were measured at a feed pressure of 5 bar. ${ }^{\mathrm{b}}$ Two coupons were tested.

Table 6 presents the zeta potential and contact angle for coated membranes with (SC498/SA190)8, (SC498/KE253)8, and (SC498/SA190) 8 SC498 combinations. 
Table 6. Zeta potentials, ZP (at pH close to 7), and contact angles, CA of (SC498/SA190) 8 , (SC498/ KE253) 8 , and (SC498/SA190) $)_{8}$ SC498 films on different substrates.

\begin{tabular}{llcc}
\hline $\begin{array}{l}\text { Substrate } \\
\text { Code }\end{array}$ & PE bilayers & $\begin{array}{c}\text { ZP } \\
(\mathrm{mV})\end{array}$ & $\begin{array}{c}\text { CA } \\
\left({ }^{\circ}\right)\end{array}$ \\
\hline A1 & $(\mathrm{SC} 498 / \mathrm{SA} 190)_{8}$ & -38.4 & 77.05 \\
$\mathrm{~A} 2$ & $(\mathrm{SC} 498 / \mathrm{KE} 253)_{8}$ & -24.4 & 79.69 \\
$\mathrm{~A} 4$ & $(\mathrm{SC} 498 / \mathrm{SA} 190) \square \mathrm{SC} 498$ & -23.5 & 77.19 \\
\hline $\mathrm{B} 1$ & $(\mathrm{SC} 498 / \mathrm{SA} 190)_{8}$ & -32.0 & 55.00 \\
$\mathrm{~B} 2$ & $(\mathrm{SC} 498 / \mathrm{KE} 253)_{8}$ & -22.6 & 75.23 \\
$\mathrm{~B} 4$ & $(\mathrm{SC} 498 / \mathrm{SA} 190) \square \mathrm{SC} 498$ & -21.9 & 74.51 \\
\hline $\mathrm{C} 1$ & $(\mathrm{SC} 498 / \mathrm{SA} 190)_{8}$ & -26.2 & 46.55 \\
$\mathrm{C} 2$ & $(\mathrm{SC} 498 / \mathrm{KE} 253)_{8}$ & -26.4 & 65.02 \\
$\mathrm{C} 4$ & $(\mathrm{SC} 498 / \mathrm{SA} 190) \square \mathrm{SC} 498$ & -20.7 & 71.48 \\
\hline
\end{tabular}

Water permeability decreased when coating layers changed from (SC498/SA190) 8 to (SC498/KE253)8. This can be related to the lower hydrophilicity of the (SC498/KE253) 8 layer, which is also confirmed by the results of contact angles in Table 6 .

To investigate the effect of altering surface charge (negative to positive) on membrane performance, a layer of SC498 was deposited on 8 bilayers of SC498/SA190. The comparison of the performance of membranes composed of (SC498/SA190) ${ }_{8} \mathrm{SC}_{\mathrm{S}} 48$ and (SC498/SA190) $)_{8}$ on different substrates in Table 5 shows that salt rejections and water permeabilities increased and decreased, respectively. This can be explained by changes in the structure, charge, and hydrophilicity of LbL-coated membrane surfaces.

The surface charge of membranes coated with (SC498/SA190) 8 SC498 still showed negative values, which was, however, somewhat less negative (neutralized to some extent) than the membrane coated just with (SC498/SA190)8 as shown in Table 6.

A hypothesis is provided in Fig. 9. The membrane coated with (SC498/SA190) ${ }_{1}$ exhibits a negatively charged surface due to the outermost SA190 layer, while its negative charge comes from the dissociation of its $-\mathrm{COOH}$ (carboxyl) groups. The structure of weak polyelectrolytes like SA190 depends on the solution $\mathrm{pH}$, and they swell if the solution $\mathrm{pH}$ is more than $\mathrm{pK}_{\mathrm{a}}$ and collapse if the solution $\mathrm{pH}$ is less than $\mathrm{pK}_{\mathrm{a}}$ [58]. The $\mathrm{pH}$ of SA190 solution used for coating was 3.5, and less than its $\mathrm{pK}_{\mathrm{a}}$ (4-5). It is likely that during the coating of the first layer of SA190 on the SC498 layer, SA190 chains form a collapsed structure, as depicted in Fig. 9. After deposition of the next layer of SC498 on (SC498/SA190), the surface charge is expected to be positive, but it is negative. The pH of SC498 coating solution was 10.5 , and more than the $\mathrm{pK}_{\mathrm{a}}$ of SA190, so the SA190 chains will become ionized 
and then swell and diffuse out to the outer surface and render a negatively charged surface $[48,59]$. The same thing happens in the subsequent layers.

The diffusion of SA190 leads to the mixing of the SC498 and SA190 layers, which creates a slightly tighter structure in the surface of the coating layer. This was seen as a lower permeability and higher salt retention in the case where the last PE layer was SC498 (Table 5), although the negative zeta potential induced by (SC498/SA190) 8 was 6-15 mV more negative than (SC498/SA190) 8 SC498. In addition, the more negatively charged (SC498/SA190) 8 membrane showed higher hydrophilicity and higher permeability (Tables 5 and 6).
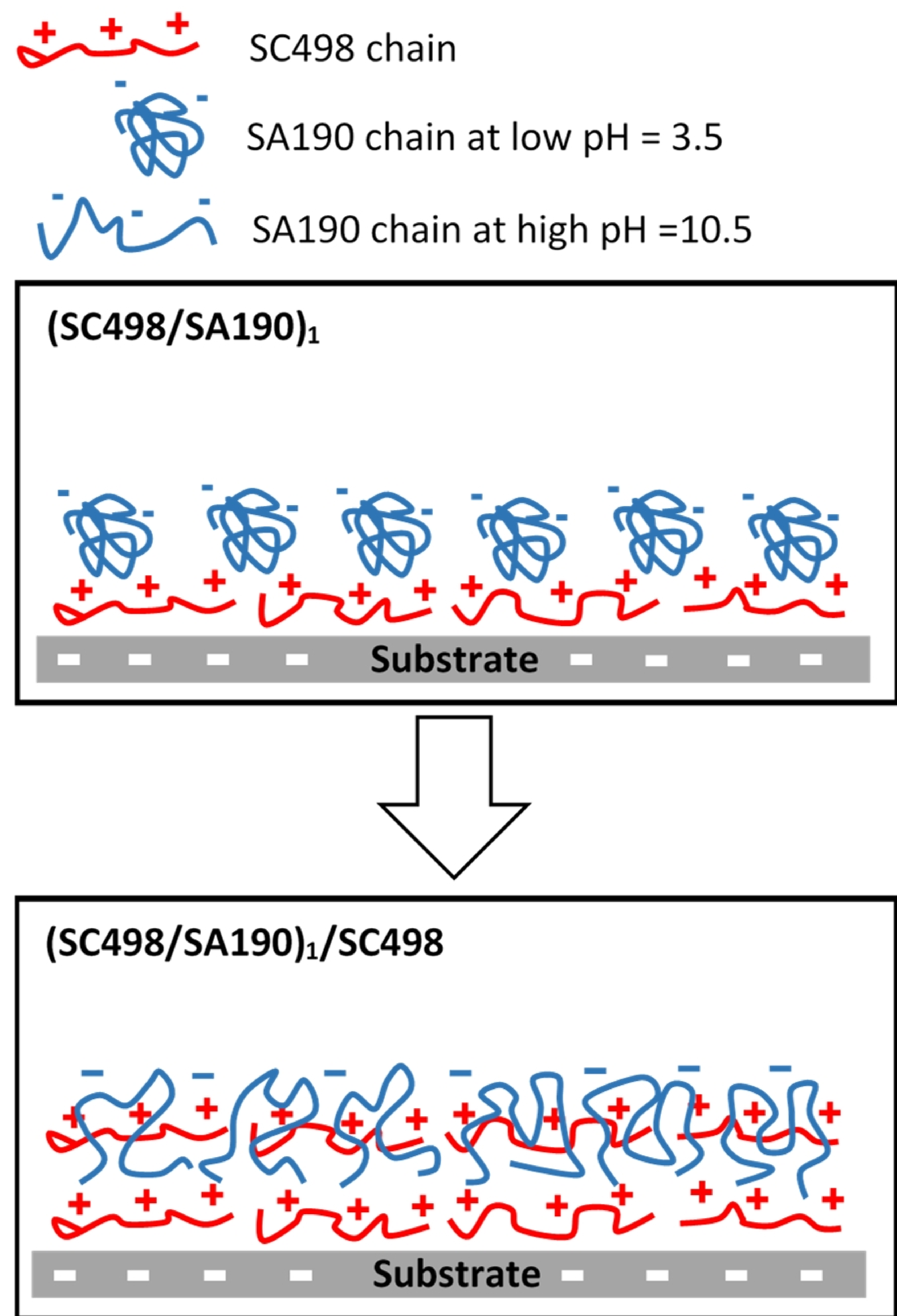

Fig. 9. Schematics of the assembly of SC498 layer on (SC498/SA190)1 layer.

\subsubsection{Comparison with commercial NF membranes}

Fig. 10 compares the salt water permeabilities and salt rejection of prepared LbL-coated membranes and two commercial NF membranes under the same test conditions. Fig. 10 shows the permeability/rejection properties of the prepared LbL-coated membranes exceeded the properties of commercial membranes in some cases. For instance, membrane B3-(F2S/SA190) $)_{8}$ rejected over $98 \%$ of $\mathrm{MgSO}_{4}$ and $88 \%$ of $\mathrm{NaCl}$ which are very good values for membranes which permeability is $9 \mathrm{~L} /\left(\mathrm{m}^{2} \mathrm{~h}\right.$ bar). This membrane represents very tight NF membranes or loose RO membranes. However, its permeability is exceptionally 
high. As Fig. 10 shows, it is also possible to achieve a membrane that rejects divalent sulfate ions but permeates monovalent ions, e.g. C1-(SC498/SA190)8, and has rejection and permeability in the same range as the NF270 membrane.

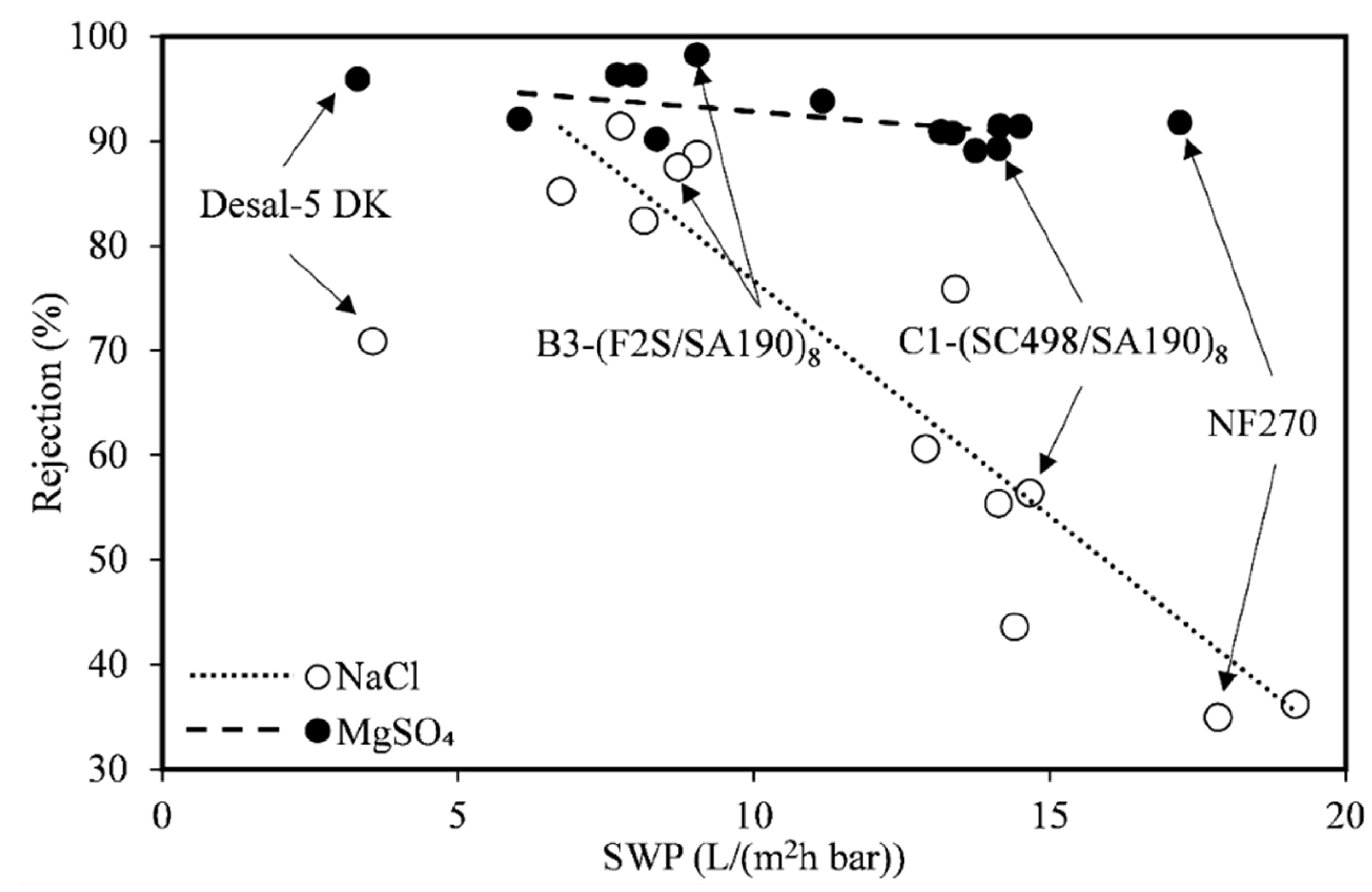

Fig. 10. Comparing the performance of LbL-coated membranes with commercial NF membranes

\subsubsection{Long-term stability of LbL-coated membranes}

Long-term stability is an important property of membranes. To investigate this parameter, the SWP and $\mathrm{R} \%$ of two prepared membranes were measured by filtering a more concentrated solution of $\mathrm{NaCl}$ (3500 ppm) for $0.5 \mathrm{~h}$ and a somewhat longer time $(10 \mathrm{~h})$. The stability of the coated layer was then evaluated by comparing the variation of SWP and R\% during these shorter and longer filtration periods.

As shown in Fig. 11, no significant changes in SWP and $\mathrm{NaCl}$ rejection $(\mathrm{R} \%)$ were observed after filtration for $10 \mathrm{~h}$. This is indicative of the appropriate stability of polyelectrolyte layers on the prepared membranes. 


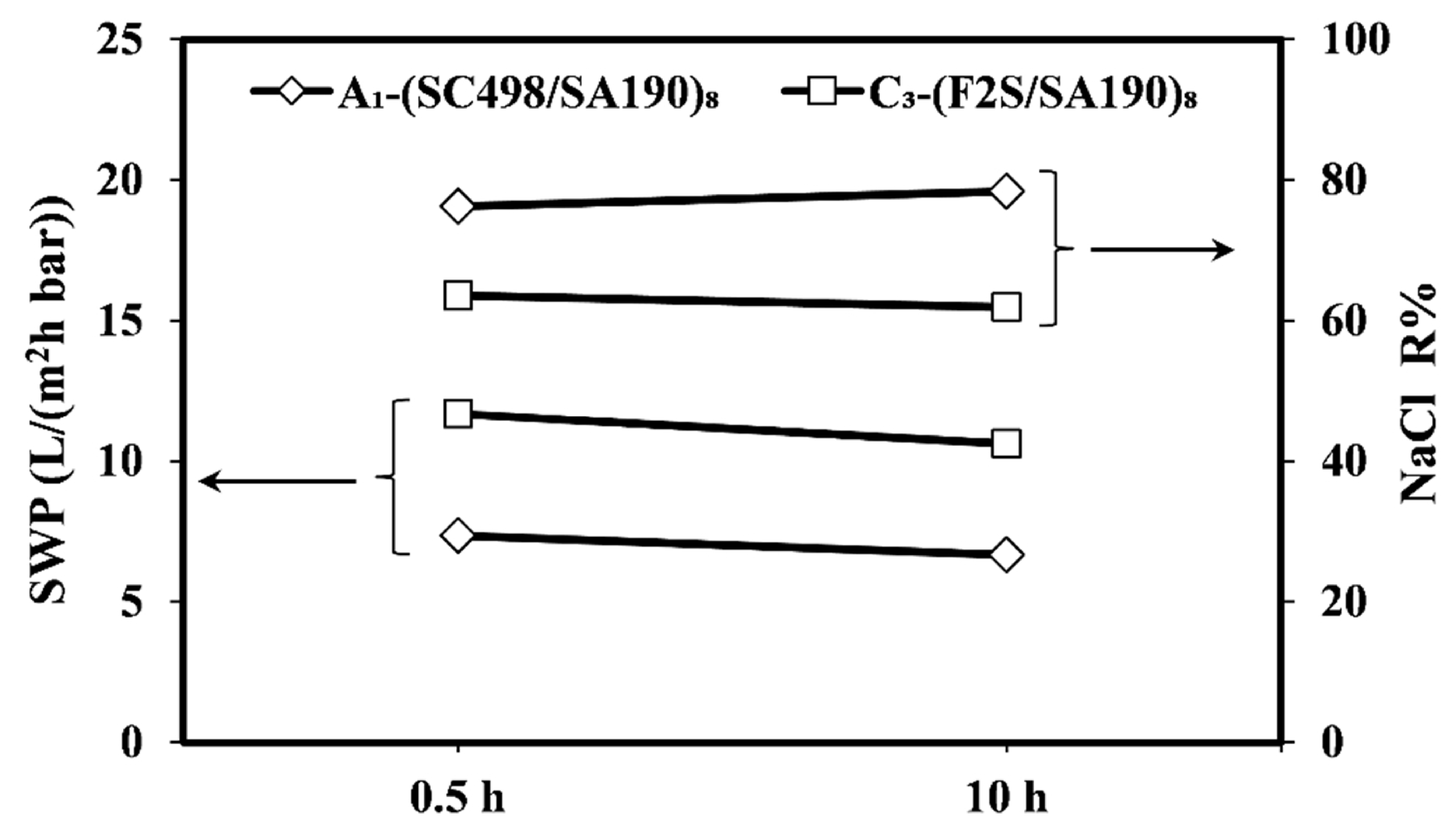

Fig. 11. Stability of two LbL-coated membranes composed of (SC498/SA190) $)_{8}$ and (F2S/SA190) 8 on $A_{1}$ and $\mathrm{C}_{3}$ substrates, respectively.

\section{Conclusions}

A new application for EoL RO membranes was presented in this study. The fluidic assembly method was used to deposit polyelectrolyte multilayers on EoL membranes after removing their fouling and the degradation of PA layer. The polyelectrolytes used were commercially available, low-price polyelectrolytes, which makes the preparation of LbL-coated membranes economically attractive. Variation in the polyelectrolyte type, substrate permeability, and the charge of the outer layer affected the water permeability and salt rejection of the prepared membranes. The greatest $\mathrm{MgSO}_{4}$ rejection (98.3\%) was obtained by coating eight bilayers of F2S/SA190 on substrates with PWP of $17.1 \mathrm{~L} /\left(\mathrm{m}^{2} \mathrm{~h}\right.$ bar). In the best case, the permeability and rejection properties of the prepared LbL-coated membranes exceeded the corresponding values of commercial membranes. The promising results, along with long-term stability of the polyelectrolyte layers, indicate the possibility of using NF membranes as prepared in this study for practical applications. The results show that by controlling the substrate properties (permeability) and the proper selection of polyelectrolytes, the properties of prepared LbL-coated membranes can be tailored toward reverse osmosis or nanofiltration.

\section{Acknowledgement}

The authors would like to thank Kemira (Finland) for the donation of the polyelectrolytes. 


\section{References}

[1] E. Coutinho de Paula, M.C.S. Amaral, Extending the life-cycle of reverse osmosis membranes: A review, Waste Management \& Research, 35 (2017) 456-470.

[2] M. Pontié, S. Awad, M. Tazerout, O. Chaouachi, B. Chaouachi, Recycling and energy recovery solutions of end-of-life reverse osmosis (RO) membrane materials: A sustainable approach, Desalination, 423 (2017) 30-40.

[3] J. Landaburu-Aguirre, R. García-Pacheco, S. Molina, L. Rodríguez-Sáez, J. Rabadán, E. GarcíaCalvo, Fouling prevention, preparing for re-use and membrane recycling. Towards circular economy in RO desalination, Desalination, 393 (2016) 16-30.

[4] International Desalination Association. Desalination by the Numbers. http://idadesal.org/, 2018, accessed December 2018.

[5] W. Lawler, J. Alvarez-Gaitan, G. Leslie, P. Le-Clech, Comparative life cycle assessment of endof-life options for reverse osmosis membranes, Desalination, 357 (2015) 45-54.

[6] E. Coutinho de Paula, M.C.S. Amaral, Environmental and economic evaluation of end-of-life reverse osmosis membranes recycling by means of chemical conversion, Journal of Cleaner Production, 194 (2018) 85-93.

[7] M. Kipper da Silva, A. Ambrosi, G.M. dos Ramos, I.C. Tessaro, Rejuvenating polyamide reverse osmosis membranes by tannic acid treatment, Separation and purification technology, 100 (2012) $1-8$.

[8] W. Lawler, T. Wijaya, A. Antony, G. Leslie, P. Le-Clech, Reuse of reverse osmosis desalination membranes. IDA World Congress, Perth Convention and Exhibition Centre Perth, Western Australia, (2011).

[9] W. Lawler, Z. Bradford-Hartke, M.J. Cran, M. Duke, G. Leslie, B.P. Ladewig, P. Le-Clech, Towards new opportunities for reuse, recycling and disposal of used reverse osmosis membranes, Desalination, 299 (2012) 103-112.

[10] E. Ould Mohamedou, D. Penate Suarez, F. Vince, P. Jaouen, M. Pontie, New lives for old reverse osmosis (RO) membranes, Desalination, 253 (2010) 62-70.

[11] M. Pontié, Old RO membranes: solutions for reuse, Desalination and Water Treatment, 53 (2015) 1492-1498.

[12] C. Prince, M. Cran, P. Le-Clech, K. Uwe-Hoehn, M. Duke, Reuse and recycling of used desalination membranes. Proceedings of OzWater'11, Adelaide, (2011).

[13] J. Morón-López, L. Nieto-Reyes, J. Senán-Salinas, S. Molina, R. El-Shehawy, Recycled desalination membranes as a support material for biofilm development: A new approach for microcystin removal during water treatment, Science of the Total Environment, 647 (2019) 785 793.

[14] R. García-Pacheco, J. Landaburu-Aguirre, P. Terrero-Rodríguez, E. Campos, F. Molina-Serrano, J. Rabadán, D. Zarzo, E. García-Calvo, Validation of recycled membranes for treating brackish water at pilot scale, Desalination, 433 (2018) 199-208.

[15] E. Coutinho de Paula, P.V. Martins, I.C.d.M. Ferreira, M.C.S. Amaral, Bench and pilot scale performance assessment of recycled membrane converted from old nanofiltration membranes, Environmental technology, (2018) 1-13. 
[16] S. Molina, J. Landaburu-Aguirre, L. Rodríguez-Sáez, R. García-Pacheco, G. José, E. GarcíaCalvo, Effect of sodium hypochlorite exposure on polysulfone recycled UF membranes and their surface characterization, Polymer Degradation and Stability, 150 (2018) 46-56.

[17] A. Ambrosi, I.C. Tessaro, Study on potassium permanganate chemical treatment of discarded reverse osmosis membranes aiming their reuse, Separation Science and Technology, 48 (2013) 1537-1543.

[18] R. García-Pacheco, J. Landaburu-Aguirre, S. Molina, L. Rodríguez-Sáez, S.B. Teli, E. GarcíaCalvo, Transformation of end-of-life RO membranes into NF and UF membranes: Evaluation of membrane performance, Journal of Membrane Science, 495 (2015) 305-315.

[19] J.J. Rodríguez, V. Jiménez, O. Trujillo, J. Veza, Reuse of reverse osmosis membranes in advanced wastewater treatment, Desalination, 150 (2002) 219-225.

[20] J.M. Veza, J.J. Rodriguez-Gonzalez, Second use for old reverse osmosis membranes: wastewater treatment, Desalination, 157 (2003) 65-72.

[21] H.D. Raval, V.R. Chauhan, A.H. Raval, S. Mishra, Rejuvenation of discarded RO membrane for new applications, Desalination and Water Treatment, 48 (2012) 349-359.

[22] W. Lawler, A. Antony, M. Cran, M. Duke, G. Leslie, P. Le-Clech, Production and characterisation of UF membranes by chemical conversion of used RO membranes, Journal of membrane science, 447 (2013) 203-211.

[23] M.R. Moradi, M.P. Chenar, S.H. Noie, M. Hesampour, M. Mänttäri, PDMS coating of used TFC$\mathrm{RO}$ membranes for $\mathrm{O}_{2} / \mathrm{N}_{2}$ and $\mathrm{CO}_{2} / \mathrm{N}_{2}$ gas separation applications, Polymer Testing, 63 (2017) 101-109.

[24] E. Coutinho de Paula, J.C.L. Gomes, M.C.S. Amaral, Recycling of end-of-life reverse osmosis membranes by oxidative treatment: a technical evaluation, Water Science and Technology, (2017) 605-622.

[25] G. Decher, Fuzzy nanoassemblies: toward layered polymeric multicomposites, science, 277 (1997) 1232-1237.

[26] L. Ouyang, R. Malaisamy, M.L. Bruening, Multilayer polyelectrolyte films as nanofiltration membranes for separating monovalent and divalent cations, Journal of Membrane Science, 310 (2008) 76-84.

[27] W. Jin, A. Toutianoush, B. Tieke, Use of polyelectrolyte layer-by-layer assemblies as nanofiltration and reverse osmosis membranes, Langmuir, 19 (2003) 2550-2553.

[28] R. Malaisamy, M.L. Bruening, High-flux nanofiltration membranes prepared by adsorption of multilayer polyelectrolyte membranes on polymeric supports, Langmuir, 21 (2005) 1058710592.

[29] W. Shan, P. Bacchin, P. Aimar, M.L. Bruening, V.V. Tarabara, Polyelectrolyte multilayer films as backflushable nanofiltration membranes with tunable hydrophilicity and surface charge, Journal of membrane science, 349 (2010) 268-278.

[30] J. de Grooth, R. Oborný, J. Potreck, K. Nijmeijer, W.M. de Vos, The role of ionic strength and odd-even effects on the properties of polyelectrolyte multilayer nanofiltration membranes, Journal of membrane science, 475 (2015) 311-319. 
[31] A. Toutianoush, W. Jin, H. Deligöz, B. Tieke, Polyelectrolyte multilayer membranes for desalination of aqueous salt solutions and seawater under reverse osmosis conditions, Applied surface science, 246 (2005) 437-443.

[32] L.Y. Ng, A.W. Mohammad, C.Y. Ng, C.P. Leo, R. Rohani, Development of nanofiltration membrane with high salt selectivity and performance stability using polyelectrolyte multilayers, Desalination, 351 (2014) 19-26.

[33] B.W. Stanton, J.J. Harris, M.D. Miller, M.L. Bruening, Ultrathin, multilayered polyelectrolyte films as nanofiltration membranes, Langmuir, 19 (2003) 7038-7042.

[34] J. Kochan, T. Wintgens, J.E. Wong, T. Melin, Properties of polyethersulfone ultrafiltration membranes modified by polyelectrolytes, Desalination, 250 (2010) 1008-1010.

[35] T. Laakso, M. Kallioinen, A. Pihlajamäki, M. Mänttäri, J.-E. Wong, Polyelectrolyte multilayer coated ultrafiltration membranes for wood extract fractionation, Separation and Purification Technology, 156 (2015) 772-779.

[36] C. Liu, L. Shi, R. Wang, Crosslinked layer-by-layer polyelectrolyte nanofiltration hollow fiber membrane for low-pressure water softening with the presence of SO42- in feed water, Journal of Membrane Science, 486 (2015) 169-176.

[37] Z. Lin, Q. Zhang, Y. Qu, M. Chen, F. Soyekwo, C. Lin, A. Zhu, Q. Liu, LBL assembled polyelectrolyte nanofiltration membranes with tunable surface charges and high permeation by employing a nanosheet sacrificial layer, Journal of Materials Chemistry A, 5 (2017) 1481914827.

[38] S. Ilyas, R. English, P. Aimar, J.-F. Lahitte, W.M. De Vos, Preparation of multifunctional hollow fiber nanofiltration membranes by dynamic assembly of weak polyelectrolyte multilayers, Colloids and surfaces A: Physicochemical and engineering aspects, 533 (2017) 286-295.

[39] A.M. Avram, P. Ahmadiannamini, A. Vu, X. Qian, A. Sengupta, S.R. Wickramasinghe, Polyelectrolyte multilayer modified nanofiltration membranes for the recovery of ionic liquid from dilute aqueous solutions, Journal of Applied Polymer Science, 134 (2017) 45349.

[40] Z. Huang, M. Li, N. Li, X. Tang, Z. Ouyang, Antibacterial Properties Enhancement of Layerby-Layer Self-Assembled Nanofiltration Membranes, Journal of nanoscience and nanotechnology, 18 (2018) 4524-4533.

[41] Y.-L. Ji, B.-X. Gu, Q.-F. An, C.-J. Gao, Recent advances in the fabrication of membranes containing "ion pairs" for nanofiltration processes, Polymers, 9 (2017) 715.

[42] S.M. Abtahi, L. Marbelia, A.Y. Gebreyohannes, P. Ahmadiannamini, C. Joannis-Cassan, C. Albasi, W.M. de Vos, I.F. Vankelecom, Micropollutant rejection of annealed polyelectrolyte multilayer based nanofiltration membranes for treatment of conventionally-treated municipal wastewater, Separation and purification technology, 209 (2019) 470-481.

[43] W. Cheng, C. Liu, T. Tong, R. Epsztein, M. Sun, R. Verduzco, J. Ma, M. Elimelech, Selective removal of divalent cations by polyelectrolyte multilayer nanofiltration membrane: Role of polyelectrolyte charge, ion size, and ionic strength, Journal of Membrane Science, 559 (2018) 98-106.

[44] S. Ilyas, S.M. Abtahi, N. Akkilic, H.D.W. Roesink, W.M. de Vos, Weak polyelectrolyte multilayers as tunable separation layers for micro-pollutant removal by hollow fiber nanofiltration membranes, Journal of membrane science, 537 (2017) 220-228. 
[45] N. Dizge, R. Epsztein, W. Cheng, C.J. Porter, M. Elimelech, Biocatalytic and salt selective multilayer polyelectrolyte nanofiltration membrane, Journal of Membrane Science, 549 (2018) 357-365.

[46] S.M. Abtahi, S. Ilyas, C.J. Cassan, C. Albasi, W.M. De Vos, Micropollutants removal from secondary-treated municipal wastewater using weak polyelectrolyte multilayer based nanofiltration membranes, Journal of Membrane Science, 548 (2018) 654-666.

[47] Ecolab. Safety Data Sheet, Ultrasil 110. http://safetydata.ecolab.com, 2018, accessed September 2018.

[48] C. Peng, Y.S. Thio, R.A. Gerhardt, H. Ambaye, V. Lauter, pH-promoted exponential layer-bylayer assembly of bicomponent polyelectrolyte/nanoparticle multilayers, Chemistry of Materials, 23 (2011) 4548-4556.

[49] H. Dautzenberg, W. Jaeger, J. Kötz, B. Philipp, C. Seidel, D. Stscherbina, Polyelectrolytes: formation, characterization and application, (1994).

[50] Y. Li, X. Wang, J. Sun, Layer-by-layer assembly for rapid fabrication of thick polymeric films, Chemical Society Reviews, 41 (2012) 5998-6009.

[51] J.J. Richardson, M. Björnmalm, F. Caruso, Technology-driven layer-by-layer assembly of nanofilms, Science, 348 (2015) aaa2491.

[52] Y.N. Kwon, J.O. Leckie, Hypochlorite degradation of crosslinked polyamide membranes: II. Changes in hydrogen bonding behavior and performance, Journal of membrane science, 282 (2006) 456-464.

[53] S. Molina Martínez, R. García Pacheco, L. Rodríguez-Sáez, E. García-Calvo, E. Campos Pozuelo, D. Zarzo Martínez, J. González de la Campa, J. de Abajo González, Transformation of end-of-life RO membranes into recycled NF and UF membranes, surface characterization. IDA World Congress proceeding, (2015).

[54] D.E. Sachit, J.N. Veenstra, Foulant Analysis of Three RO Membranes Used in Treating Simulated Brackish Water of the Iraqi Marshes, Membranes, 7 (2017) 23.

[55] A. Simon, L.D. Nghiem, P. Le-Clech, S.J. Khan, J.E. Drewes, Effects of membrane degradation on the removal of pharmaceutically active compounds (PhACs) by NF/RO filtration processes, Journal of Membrane Science, 340 (2009) 16-25.

[56] V.T. Do, C.Y. Tang, M. Reinhard, J.O. Leckie, Degradation of polyamide nanofiltration and reverse osmosis membranes by hypochlorite, Environmental science \& technology, 46 (2012) 852-859.

[57] Y.N. Kwon, J.O. Leckie, Hypochlorite degradation of crosslinked polyamide membranes: I. Changes in chemical/morphological properties, Journal of membrane science, 283 (2006) 21-26.

[58] G.S. Longo, M. Olvera de La Cruz, I. Szleifer, Molecular theory of weak polyelectrolyte gels: the role of $\mathrm{pH}$ and salt concentration, Macromolecules, 44 (2010) 147-158.

[59] C. Peng, Y.S. Thio, R.A. Gerhardt, Effect of precursor-layer surface charge on the layer-by-layer assembly of polyelectrolyte/nanoparticle multilayers, Langmuir, 28 (2011) 84-91. 